\title{
The Influence of Career Commitment and Workload on Academics' Job Satisfaction: The Moderating Role of a Supportive Environment
}

\author{
Jamali Janib (D), Roziah Mohd Rasdi ID , Zeinab Zaremohzzabieh \\ Faculty of Educational Studies, Universiti Putra Malaysia, Serdang, Malaysia
}

\begin{abstract}
This paper serves to study the influences of career commitment and workload on job satisfaction among academics in higher education. We investigated whether a supportive environment is a significant moderator between workload and job satisfaction. For this cross-sectional study, the stratified random sampling method yielded 191 academics from five research universities in Malaysia. Partial least squaresstructural equation modeling (PLS-SEM) showed that high levels of career commitment correspond with high levels of satisfaction at work of academics. Also, a greater workload diminishes job satisfaction among academics. The analysis of the interaction-moderation dynamics showed that a supportive environment reduces workload effects on academics' job satisfaction. This study contributes to confirming the important roles of career commitment and workload in predicting job satisfaction. It also expands literature on the buffering role of a supportive environment in the interaction between workload and job satisfaction among academics.
\end{abstract}

Keywords: academic staff; career commitment; job satisfaction; supportive environment; workload

\section{Introduction}

Higher education is the driving force in closing socio-economic inequalities within broad national development goals. The quality of higher education is integral to the human capital value that determines a country's prosperity. Countries are paying closer attention to higher education delivery, as indicated by institutional and technological reforms spearheaded by intellectually esteemed and dedicated faculties. In addition to meeting institutional requirements, job satisfaction should be promoted among academics to ensure that each university is the beneficiary of the positive impact on employees' experience at work. Indeed, academics, as success determiners, walk and talk the university's vision and mission. Escardíbul and Afcha (2017) concurred that high-quality faculty

* Corresponding author: Roziah Mohd Rasdi; roziahmohdrasdi@gmail.com 
members contribute to the success of a supportive edcational system. Therefore, academics' job satisfaction should be given utmost attention.

Job satisfaction is significant when examining the performance levels of employees and organizations. As succinctly put forth by de Lourdes MachadoTaylor et al. (2016), faculty members who are satisfied and well-motivated tend to enhance their reputation as academics, representing national and institutional standards, as well as impacting student learning in the classroom. Without a doubt, the academic workforce is the backbone behind every successful university. Previous studies have equally shown that job satisfaction directly influences the retention of academics in higher education (De Sousa Sabbagha et al., 2018). The norm is that satisfied employees pose reduced absenteeism and turnover issues to organizations and chart higher productivity (Singh \& Jain, 2013). In contrast, unsatisfied employees are less productive, leading to constant thoughts of moving on to a better job. Liu et al. (2019) called on organizations to take note of human resource goals, which include the job satisfaction of academics.

Given the importance of job satisfaction among academics, extant literature on job satisfaction predictors was reviewed, focusing on academic context. One of the most important aspects that we need to consider for academics could be increasing their job satisfaction through positive career commitment (Gendron et al., 2016). Career commitment to a given task allows employees to explore the meaning of work, and in the process, offers some recovery from emotional exhaustion. Positively, career commitment could establish the job crafting process in which academics could create the meaning of their job at emotional, social, and institutional level (Amin et al., 2017). Cerci and Dumludag (2019) highlighted that this intrinsic motivation of academics contributes to a high level of commitment, not so much attributed to the extrinsic factors of remuneration and workplace conditions. Another employee job satisfaction determiner is workload assigned. Literature has shown that in recent decades, the research on workload issues has gained momentum and undergone scrutiny. Higher education institutions around the world have noted it as a serious concern (Tight, 2010).

In the distant past, the working conditions and requirements of university teaching were relatively less demanding, such that employees enjoyed less academic constraints and pressure (Mudrak et al., 2018). Following global changes, universities have undergone a shift in quality and standards, resulting in managing higher expectations on performance (Wolf et al., 2021). Without a doubt, academics' performance is now more complex, characterized by the function of universities in the duality of generating and transmitting knowledge through various teaching and research endeavors (Houston et al., 2006). According to Akob (2016), there is a significant connection in the mix of workload, work ethics of educators and job satisfaction, and work execution performance. Besides, work overload impacts educators' job satisfaction negatively (Imondi, 2011), where teachers have commonly professed that an excess of workload strongly relates to low performance. In the same vein, lecturers subjected to excessive workload in the form of academic activities have been reported to 
experience lower job satisfaction (Sabagh et al., 2018). Song et al.'s (2013) study further validated that excessive workload is the main cause of defusing job satisfaction. Ahmad et al. (2015) researched pharmacy academics' level of workload and job satisfaction in India's public and private universities. More than half $(57.9 \%)$ of the cohort professed their satisfaction over the amount of workload they have. Generally, private-sector faculty members have reported that a greater burden of teaching load resulted in diminishing satisfaction levels.

Past researchers have advocated the use of specific resources to manage the negative effects of heavy workload (Ahmad et al., 2015). One of the resources that has been robustly examined is how a supportive environment moderates the interaction between workload and job satisfaction (Marsaditha, 2017). It makes sense for organizations to maintain a learning and working ecosystem that fosters a valued workforce (Caldana et al., 2021). Organizations are obligated to provide a sustainable supportive environment that nurtures employees' positive growth and performance outcomes (Newman et al., 2018). Accordingly, "organizational support" is the vital element for employee performance, characterized as an individual's effort, support, and ability (Laihonen \& Mäntylä, 2017). Researchers have found that a workplace ecosystem that provides a supportive camaraderie results in positive employee outcomes, in particular job satisfaction (Berberoglu, 2018).

It is interesting to note that although the value of a supportive environment is widely recognized and researched, there is a resounding gap in the investigation of its effect on the interactions between workload and job satisfaction, more so in faculty settings. Responding to this, this study aimed to provide empirical evidence of the benefits of a supportive environment among academics. We examined if a supportive environment could moderate the relationship between workload and job satisfaction. Therefore, this study aims to study the performance of academics by investigating: (i) the link between career commitment and workload with job satisfaction, and (ii) the moderating role of a supportive environment on the relationship between workload and job satisfaction.

\section{Theoretical Background and Hypothesis Testing}

In this study, Herzberg's (1959) two-factor theory of motivation is utilized to determine which motivational factors are linked to job satisfaction among academics in Malaysian research universities. Herzberg's two-factor theory has been widely used in employee satisfaction research (Alrawahi et al., 2020). According to Herzberg's theory of motivation, there are two categories of motivating factors applied to the workplace - satisfiers and dissatisfiers (Herzberg, 1966). According to this theory, in order to increase productivity, satisfiers and dissatisfiers must be identified and addressed. A previous study has revealed that a heavy workload is a major source of dissatisfaction in organizations (Halder, 2018). Employees, according to Herzberg et al. (1959), are dissatisfied with the fulfilling of lower order requirements at work, such as those related to minimum pleasant working conditions. On the other hand, other studies have shown that recognition for high commitment to do something 
meaningful and a supportive environment in organizations are the main sources of satisfaction (Agbozo et al., 2017; Indarti et al., 2017). The motivators provide positive satisfaction, arising from intrinsic conditions of the job itself. Acknowledging this theory, workload was identified as a negative factor of job satisfaction in this study, while career commitment and a supportive environment were identified as positive ones.

\subsection{Career Commitment and Job Satisfaction}

Dorenkamp and Ruhle (2019) defined career commitment as the level of desire to work in a certain field. Initially, career commitment was thought to be a professional obligation for professionals. As defined by Hall et al. (2018), a career is a set of events and activities associated with a person's life-long employment. Thus, the notion of career dedication has shifted from professionals to anybody who establishes a career. It was further characterized as the emotional notion of linking career commitment with a connection to one's career objectives, the emotional concept of equating oneself with the work required in a specific area, and the capacity to persevere in pursuing career goals in following research (Kim et al., 2020). In sum, career commitment refers to a strong psychological attachment to one's present field of work and a firm psychological mindset of continuing to do a series of duties relevant to that profession.

Job satisfaction can be defined as the employee's subjective feelings towards how satisfied they are at the workplace based on their state of physical and psychological well-being (Hsiao \& Lin, 2018). Indeed, job satisfaction is determined as a basic and principal factor that can be the main cause of performance, behavior, and staff reactions at the workplace (Hee et al., 2019). Accordingly, Choi and Chiu (2017) suggested the possibility of a link between an employee's work satisfaction and commitment to their career. Xie et al. (2017) believed that an individual's positive attitude towards career identification would improve their job satisfaction and thus reduce their turnover intention. On this basis, Duffy et al. (2017) showed that the level of professional commitment is directly related to the employee's satisfaction at work. If an employee has a high degree of identification with their occupation, their feelings about work would not be affected by external conditions such as salary, promotion, and so on. Therefore, we formulated the following hypothesis:

$\mathbf{H}_{\mathbf{1}}$ : Career commitment has a positive effect on job satisfaction among academics.

\subsection{Workload and Job Satisfaction}

Inegbedion et al. (2020) defined employee workload as the perceived relationship between the volume of mental processing or resources required and the completion of a task. Researchers have provided empirical evidence that workload affects job performance and satisfaction (Liu \& Lo, 2018). Osifila and Aladetan (2020) studied the workload of lecturers at Adekunle Ajasin University. They found that excessive workload assigned to lecturers reduced their job satisfaction causing an adverse effect on performance. Increased workload intensity thus hampers academics' work performance. Liu and Lo (2018) also determined an important relationship between workload, news autonomy, and 
burnout. The researchers reported a significant negative relationship between the interaction of burnout and job satisfaction that affect turnover intention significantly. Kenny (2018) observed that when workload and pressure are increased, academics' job satisfaction diminishes. A mounting workload has been observed as the main contributor to stress, against the backdrop of an absence of recognizing effort being put in. Unsurprisingly, demotivation and poor work performance ensue. It is well recognized that academics are motivated to deliver their core skills of teaching and research. However, being subjected to obstacles, the pursuit of academic interests is hindered, thus significantly affecting overall job satisfaction (Kenny, 2018). Given these empirical findings, we formulated the following hypothesis:

$\mathbf{H}_{2}$ : Workload has a negative effect on job satisfaction among academics.

\subsection{Moderating Effects of Supportive Environment}

A supportive environment is characterized as a workplace ecosystem that hosts supervisory or peer support. It also has elements of constraints and opportunities for individuals to perform learned skills as they work (Bibi et al., 2018). Within a supportive environment, employees enjoy support and encouragement from peers and the management. Researchers have identified support from supervisors, the organization, and peers as factor affecting the work environment (Chong \& Thi, 2020). The legacy theories of organizational and social support have promoted how "organizational support" establishes affective commitment among employees, strengthening the employees' emotional bond towards their organization (Suifan et al., 2018). Given this, it makes sense for higher education institutions to nurture a supportive environment to meet diverse sectoral challenges in the present and future.

It has been observed that employees in a supportive environment enjoy a boost of interest towards their job, which translates into improved productivity (Prieto \& Pérez-Santana, 2014). In addition, it provides valuable inputs for employees regarding desired workplace behavior, which also promotes innovative work behavior. A notable study reported that excessive workload coupled with vague or opposing role demands inevitably creates undesirable work experiences. In terms of supervisory support, employees respond positively to some degree of work practice that calls for their self-directedness and autonomy (Clarke, 2015). Employees who are highly satisfied with their jobs enjoy various aspects of their jobs and meaningful friendships with co-workers. At the workplace, an employee's capacity to build supportive relationships is one of the requisites of a productive environment (Clarke, 2015).

On the contrary, the act of organizations extending support may be subjected to negative reactions from employees. According to social exchange theorists, employees establish relationships if they deem the benefits offered to be worthwhile and administered fairly (Ali et al., 2020). However, in a highly demanding environment, it is more likely that valuable benefits and fair conditions will be violated. Employees competing in highly demanding jobs can account for their stress as a cost of investment incurred from staying in their work 
organization. When job pressure is high, these employees tend to view their organization's supportive actions negatively because they perceive them as being in the self-interest of the organization or management. The employees feel that these supportive actions do not particularly benefit or suit their work situations (Naseer et al., 2018). Therefore, highly demanding environments may hinder an organization's efforts to establish social exchange relationships with potential benefits. As a result, this negative effect may reveal itself in the form of lower job productivity. Also, with the lack of social exchange relationships, the workplace may see increasing turnover, reduced commitment, and diminishing job satisfaction. This logical structure is referenced against the model of an "energy reservoir", where the coping energy of employees is used for positive behavior or adopt potentially harmful consequences within their organization (Naseer et al., 2018). From this follows our next hypothesis:

$\mathbf{H}_{3}$ : A supportive environment moderates the relationship between workload and job satisfaction among academics.

\section{Methodology}

\subsection{Study Design and Participants}

This study was a cross-sectional study. The model in this study is quite similar to the model employed in a previous study that used the same data set (Janib et al., 2021). The population of this study consisted of faculty members serving five Malaysian research universities, including USM, UM, UPM, UKM, and UTM. A total of 191 respondents were selected through stratified random sampling. The sample consisted of 102 males and 89 females, with an average age of 45 years. From the sample, $87 \%$ were married, $11 \%$ single, and $2 \%$ widowed. About $93.2 \%$ were PhD holders and only $6.8 \%$ of the respondents had a master's degree as their highest academic qualification. Regarding academic position, $13.1 \%$ were professors and $33.5 \%$ associate professors, followed by senior lecturers $(47.6 \%)$ and lecturers (5.8\%). In terms of employment, $49.1 \%$ of the respondents stated that they were involved in various administrative positions at the faculty level, such as the dean of faculty (3.5\%), the deputy dean (18.4\%), and head of the department $(27.2 \%)$. The remaining $50.9 \%$ were appointed in other positions. Table 1 shows the academic background of the respondents.

Table 1: Respondents' area of study $(\mathrm{N}=191)$

\begin{tabular}{|c|c|c|}
\hline Background & $\mathbf{n}$ & $\mathbf{\%}$ \\
\hline Engineering and architecture & 46 & $24.08 \%$ \\
\hline Social sciences & 32 & $16.7 \%$ \\
\hline Physical sciences & 29 & $15.18 \%$ \\
\hline Medical sciences and health sciences & 26 & $13.6 \%$ \\
\hline Business and administrations & 21 & $10.99 \%$ \\
\hline Humanities and arts & 20 & $10.47 \%$ \\
\hline Education & 17 & $8.98 \%$ \\
\hline
\end{tabular}

\subsection{Procedure}

Permission to complete the questionnaire was then sought from the respective universities and faculty deans. After respondents had signed a consent form, the questionnaires were distributed. Data were collected over a period of two months, 
wherein the respondents spent an average of 30 minutes on questionnaire completion. A total of 250 questionnaires were distributed with a return rate of 78\% (195 questionnaires). We excluded four incomplete questionnaires, leaving only 191 questionnaires for this study.

\subsection{Measures}

\subsubsection{Career commitment}

The scale of Blau (1985) was utilized to measure career commitment. Some sample items are: "I don't want to give up my advocacy work since I enjoy it" and "I am dissatisfied with my career as a lawyer" (reverse-scored). A five-point scale assessed this measure, ranging from 1 (strongly disagree) to 5 (strongly agree). This scale has a Cronbach alpha of 0.90 .

\subsubsection{Job satisfaction}

This measure was assessed using a scale developed by Ather and Nimlathasan (2006). The sample items of this six-item scale included: "What level of satisfaction do you have with the nature of the work you do?" and "How pleased are you with your present career position, given everything?" A five-point scale assessed this measure, ranging from 1 (very dissatisfied) to 5 (very satisfied). This scale has a Cronbach alpha of 0.79 .

\subsubsection{Workload}

This component of the construct consisted of nine items, including academic workloads in management over the past 12 months; education and researchrelated activities, both in terms of quality and quantity; sufficient time; and a sufficient number of consultations (Houston et al., 2006). A sample item is: "I often need to work after hours to meet my work requirements." The responses were obtained using a five-point Likert scale. This scale ranged from the lowest score of 1 (strongly disagree) to the highest score of 5 (strongly agree). This scale has a Cronbach alpha of 0.872 .

\subsubsection{Supportive environment}

This construct was measured using an adaptation of four multiple-item scales, which are perceived climate, supervisory relationship, peer group interaction, and perceived organizational support (Eisenberger et al., 1986). Before deployment, modifications were made on two scales, supervisory relationship and perceived organizational support. All the responses were obtained using a five-point Likert scale. This scale ranged from the lowest score of 1 (strongly disagree) to the highest score of 5 (strongly agree). This scale has a Cronbach alpha of 0.801 .

\section{Statistical Methods}

Data analysis was conducted using components-based structural equation modeling (SEM) with the support of the SmartPLS v. 3.3.3. The partial least square (PLS) method yielded numerous advantages to this study. First, it is suitable to analyze a proposed model that studies a small sample size. Next, it is insensitive to data normality and is proficient in the analysis of complex path models. Finally, the PLS method allows the analysis of moderation (Ringle et al., 2020). After making comparisons against various regression models, we decided on the PLS 
method as it better serves complex study models, such as the one in this study. In addition, this method is suitable as an analysis technique for this study as it has a small sample size $(\mathrm{N}=191)$ (Hair et al., 2019).

We employed the interaction-moderation method to test if the supporting environment moderates the association between workload and job satisfaction. Then, a bootstrapping procedure was conducted and the standard error for $t$ value computation was obtained. Mean effects are significant at 0.05 when confidence intervals do not contain zero. The evaluation of model fit was conducted by both the standardized root mean square residual (SRMR) and Bentler-Bonett normed fit index (NFI). The discrepancies between observed and anticipated correlations were assessed by SRMR. Meanwhile, NFI displays the goodness-of-fit incremental measure.

\section{Results}

\subsection{Measurement Model}

We maintained all items, as the results indicated factor loading scores above 0.60 . Table 2 shows that each research variable item achieved convergent validity. As mentioned by Hair Jr et al. (2014), convergent validity is achieved with the following values: average variance extracted $(\mathrm{AVE})=0.50$, composite reliability $(C R)=0.70$, and Cronbach alpha $=0.70$, respectively (see Table 2 ).

Table 2: Partial least squared- confirmatory factor analysis results

\begin{tabular}{|c|c|c|c|c|c|c|}
\hline Construct & No. of items & a & rho_A & CR & AVE & VIF \\
\hline CC & 7 & 0.879 & 0.888 & 0.907 & 0.582 & 1.77 \\
\hline WL & 7 & 0.778 & 0.801 & 0.847 & 0.527 & 1.175 \\
\hline JS & 7 & 0.898 & 0.903 & 0.919 & 0.620 & 1.54 \\
\hline SE & 17 & 0.933 & 0.988 & 0.965 & 0.618 & 1.014 \\
\hline
\end{tabular}

Note. $\mathrm{CC}=$ career commitment, $\mathrm{WL}=$ workload, $\mathrm{JS}=$ job satisfaction, $\mathrm{SE}=$ supportive environment, $\mathrm{VIF}=$ Variance inflation factor.

Discriminant validity was tested. We found that the square root of each construct's AVE was larger than the correlation values of the other constructs, according to the Fornell-Larcker criteria (see Table 3). The Heterotrait-Monotrait (HTMT) values were smaller than 0.85 (range 0.122 to 0.513 ) (Franke \& Sarstedt, 2019).

Table 3: Measurement model: discriminant validity

\begin{tabular}{|l|c|c|c|c|c|c|c|c|}
\hline & & \multicolumn{3}{|c|}{ Fornell-Larcker criterion } & \multicolumn{3}{c|}{ HTMT } \\
\hline & Construct & $\mathbf{1}$ & $\mathbf{2}$ & $\mathbf{3}$ & $\mathbf{4}$ & $\mathbf{1}$ & $\mathbf{2}$ & $\mathbf{3}$ \\
\hline $\mathbf{1}$ & JS & $\mathbf{0 . 7 8 8}$ & & & & & & \\
\hline $\mathbf{2}$ & CC & 0.467 & $\mathbf{0 . 7 6 3}$ & & & 0.513 & & \\
\hline $\mathbf{3}$ & SE & 0.141 & 0.074 & $\mathbf{0 . 7 8 6}$ & & 0.122 & 0.094 & \\
\hline $\mathbf{4}$ & WL & -0.305 & -0.376 & 0.056 & $\mathbf{0 . 7 2 6}$ & 0.341 & 0.460 & 0.137 \\
\hline
\end{tabular}

Note. JS = job satisfaction, $\mathrm{CC}=$ career commitment, $\mathrm{SE}=$ supportive environment, $\mathrm{WL}=$ Workload 


\subsection{Structural Model}

$\mathrm{H}_{1}$ and $\mathrm{H}_{2}$ were evaluated by path analysis. The path coefficients, coefficient of determination $\left(\mathrm{R}^{2}\right)$, and predictive relevance $\left(\mathrm{Q}^{2}\right)$ of the structural model were all evaluated. To obtain the $\beta$ and associated $t$-values, the model was evaluated using a nonparametric bootstrapping technique with a resample of 5,000 (Table 4).

Table 4: Structural model (bootstrapping)

\begin{tabular}{|c|c|c|c|c|c|c|c|c|c|}
\hline \multicolumn{2}{|c|}{ Path } & $\beta$ & SE & $\boldsymbol{P}$ & $\boldsymbol{t}$ & \multicolumn{2}{c|}{$\begin{array}{c}\text { Bias corrected } \\
\text { bootstrap (95\%) }\end{array}$} & \multirow{2}{*}{ Decision } \\
\cline { 5 - 9 } & & & & & LL & UL & \\
\hline $\mathrm{CC}$ & $\rightarrow$ & $\mathrm{JS}$ & 0.41 & 0.099 & 0.000 & 4.148 & 0.005 & 0.194 & Supported \\
\hline $\mathrm{WL}$ & $\rightarrow$ & $\mathrm{JS}$ & -0.178 & 0.088 & 0.042 & 2.036 & -0.021 & -0.315 & Supported \\
\hline $\mathrm{JS}$ & & & $\mathrm{R}^{2}$ & $\mathrm{Q}^{2}$ & & & & & \\
\hline
\end{tabular}

Note. $\mathrm{CC}=$ career commitment, $\mathrm{JS}=$ job satisfaction, $\mathrm{WL}=$ workload

The $\mathrm{R}^{2}$ statistic was used to quantify the variation in job satisfaction based on career commitment and workload. Job satisfaction had an $\mathrm{R}^{2}$ of 0.254 , indicating a weak association (Henseler et al., 2015). Collinearity was determined by computing VIF values, which were less than 5 for all constructs in the investigation, suggesting that collinearity did not pose a concern (Henseler et al., 2015). Job satisfaction had a medium predictive significance in $Q^{2}$, with a score of 0.335 . Thus, the model fit well due to SRMR values less than 0.08 and NFI values greater than 0.8 (Henseler et al., 2016). According to Henseler et al. (2015), when the SRMR is less than 0.10, the overall fit of the PLS structural model can be validated.

The results from the structural model showed a significant positive relationship between career commitment and job satisfaction $(\beta=0.41, t=4.148, p<0.000)$, and a significant negative association between workload and job satisfaction $(\beta=$ $0.178, t=2.036, p<0.042)$. As shown in Figure 1 , these results support $\mathrm{H}_{1}$ and $\mathrm{H}_{2}$ (see Table 4).

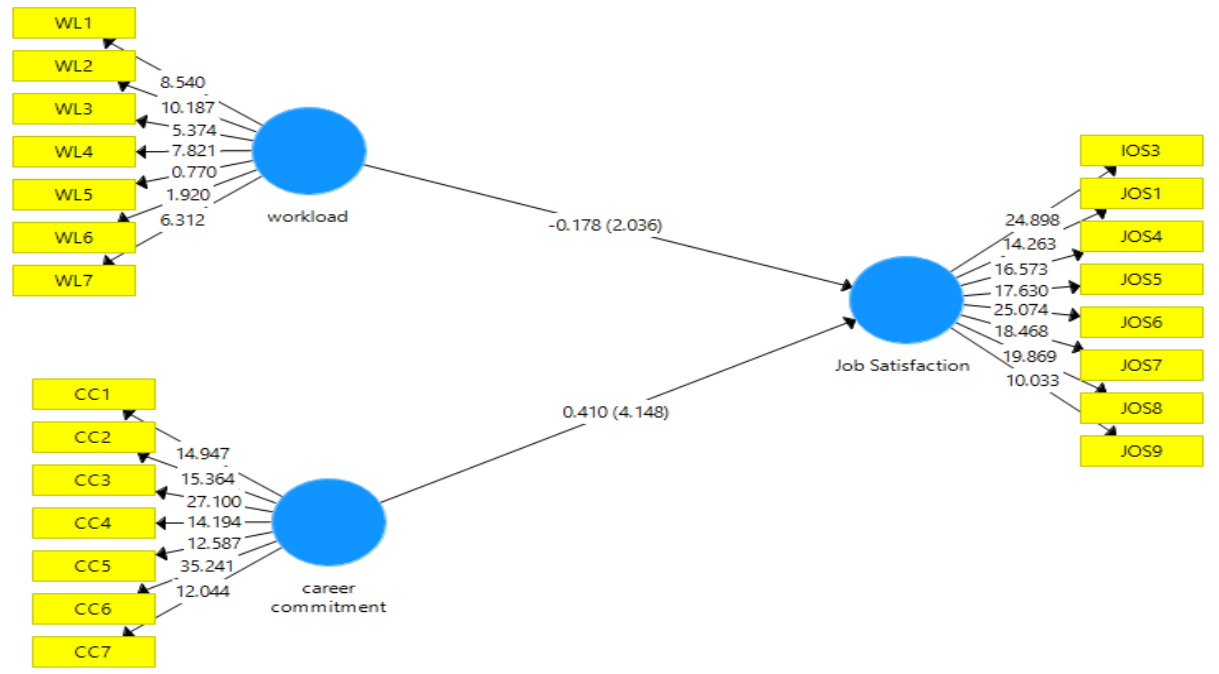

Figure 1: Structural model for job satisfaction in academics 


\subsection{Moderating Effect of Supportive Environment}

The moderating impact of a supportive environment on the connection between workload and job satisfaction was investigated using the interaction-moderation approach in Smart-PLS. According to Hair Jr et al. (2020), moderation, according to this approach, distinguishes between the roles of the two factors involved in the interaction. The outcomes revealed significant relationships between supportive environment and job satisfaction $(\beta=0.178, t=1.987, p<0.038)$, and between workload and job satisfaction $(\beta=-0.512, \mathrm{t}=2.036, \mathrm{p}<0.042)$. The interaction between workload and supportive environment had a negative and significant relationship with job satisfaction $(\beta=-0.165, \mathrm{t}=3.61, \mathrm{p}<0.001)$, indicating that supportive environment played a moderating role in the link between workload and academics' job satisfaction. Thus, $\mathrm{H}_{3}$ is supported.

\section{Discussion and Implications}

The PLS-SEM results are consistent with those of prior studies (Al-Sada et al., 2017) which reported that greater career commitment was closely linked to greater levels of job satisfaction among Indian and Qatari university faculty members. Most studies have argued that career commitment has a significant and positive influence on job satisfaction (Zhang et al., 2014). It thus follows that highly committed academics would not compromise on high standards of professionalism, would chart a prolific career, and would thus become highly satisfied with their jobs. Even if the high career commitment levels increase in congruence with job satisfaction levels, the momentum may not be sustained at a high level without the intervention of training and development for career growth. Therefore, training and development programs employing psychological assessment could be expanded to play a major role in providing opportunities where academics perceive the type of regulatory focus that they have and adjust it according to the job situation. Psychological assessments can be conducted to confirm which regulatory focus they have. Academics may be encouraged to have a promotion focus for academic positions through training and development sessions.

Another finding that was consistent with past studies is that a heavier workload is linked to low levels of job satisfaction among staff (Hee et al., 2019). This finding is also in line with Toropova et al.'s (2021) study that found workload influences job satisfaction. Correspondingly to improve job satisfaction, organizations can reconsider the amount of work loaded onto their employees, as it has been observed that an excessive workload causes great dissatisfaction (Liu \& Lo, 2018). A descriptive clarification of this finding is that work-induced stress, such as pressures and extended working hours, can lead to multiple health risks that impact the quality of work among staff, ultimately diminishing job satisfaction (Purba, 2017). In the absence of good self-regulation, employees subjected to high work pressure can experience interpersonal conflict, which results in inferior performance.

Unsurprisingly, high job satisfaction will influence the staff's productivity. Therefore, seeking a balanced workload should be a priority, because failure to do so will result in health and psychological consequences on academics. Human resource (HR) managers should be concerned about managing staff perceptions 
of workload balance as these influence how satisfied they are with their job, which translates into staff turnover and performance. Thus, university HR managers should first measure employees' displayed talents and capabilities within their work conditions before tasks are defined and assigned. For assignments that are challenging, direction and supervision should be provided, including reasonable and negotiable deadlines, so that academics can achieve optimal quality in task completion. New assignments should be accompanied by clear instructions and ready assistance. Accordingly, managers should adjust assignment loads against employees' physical and cognitive abilities. The desired outcomes of these efforts are proper task execution, employees feeling satisfied with the results of their work, and a maintained motivation in task completion.

This research has made a significant contribution to the field of human resource management (HRM). Although numerous studies on employee workload have been conducted, none have confirmed that a supportive environment could reduce the effects of workload and increase the likelihood of job satisfaction among academics.

Our interaction-moderation analysis showed that a supportive environment mitigates the impact that workload has on job satisfaction among Malaysian university academics. This moderating role of a supportive environment can be potentially clarified. Academics will adjust their perception about workload and work-related problems upon receiving support from their co-workers and supervision from superiors. In addition, they will practice autonomy/authority for work completion. Our results also demonstrated that a healthy workplace ecosystem incorporating elements of managerial support, a supportive work environment, and open communication with superiors would boost the satisfaction of academics. Understandably, the features of a supportive environment act as a protective cushion against workload which provides potential satisfaction among academics in Malaysian higher education. We deduce that by improving the features of a supportive environment in higher education, the mental workload of academics would decrease and job satisfaction would increase. As an extension, organizational best practices should incorporate aspects of employee communication, reward, recognition, and employee development as a means to foster robust engagement within the organization. In summary, the dynamism of supportive faculty environments should be encouraged and nurtured in universities to realize motivation and retention goals.

\section{Limitations and Recommendations}

The current study had some limitations. The sample size was small, data collection was conducted on a self-reporting basis, and a cross-sectional method was used. We therefore recommend that future studies examine a larger sample size using the longitudinal method. Another recommendation is the use of other data collection methods, specifically interviews and observations. Faced with an unequal gender sample size between the male group (102) and the female group (89), we found it impossible to conduct a variance analysis for the proposed model. Therefore, future studies should benefit from a variance analysis for gender on the proposed model, accounting for approximate and equal sample 
sizes of male and female respondents. As far as geographical and cultural contexts are concerned, this study was limited to a sub-context within the Malaysian context of public universities. As such, cross-regional, cross-national, and crossinstitutional generalizations and comparisons of the findings and conclusions should be done with caution. Finally, we suggest that future research include other Asian countries and other types of universities, such as private universities, and to place performance at the core of such research. As our study was only restricted to workload as the sole job demand, future studies should consider other job demands and resources, because these may provide comprehensive information into how the faculty workplace may affect its academics' ability to function. Notwithstanding, we cautioned workload as a hindrance stressor, while other studies either reported it as a challenge stressor or a stressor with curvilinear effects, such that an individual's functioning may not chart adverse effects before a threshold. Further study could scrutinize if workload presents counterintuitive effects on academics' function quality in higher education.

\section{Conclusion}

This study intended to expand the literature by developing an integrated model that articulates the theoretical linkages among career commitment, workload, and job satisfaction of academics in Malaysia. The results provided support for the hypothesized model linking career commitment, workload, and job satisfaction. The study found that career commitment is one of the intrinsic aspects that increases job satisfaction among Malaysian academics in universities. On the other hand, the results of the study suggest that workload has a negative influence on job satisfaction. These findings shed some light on how career commitment and workload influence the job satisfaction of academics in universities and colleges. Furthermore, this study provided a deeper understanding of the role of a supportive environment as a moderator between workload and job satisfaction among academics. This has implications for human resource development in higher education, through which highly skilled personnel, such as academics, are trained and developed.

\section{References}

Agbozo, G. K., Owusu, I. S., Hoedoafia, M. A., \& Atakorah, Y. B. (2017). The effect of work environment on job satisfaction: Evidence from the banking sector in Ghana. Journal of Human Resource Management, 5(1), 12-18. https://doi.org/10.11648/j.jhrm.20170501.12

Ahmad, A., Khan, M. U., Srikanth, A. B., Patel, I., Nagappa, A. N., \& Jamshed, S. Q. (2015). Evaluation of workload and its impact on satisfaction among pharmacy academicians in Southern India. Journal of Clinical and Diagnostic Research: JCDR, 9(6), 1-6. https://doi.org/10.7860/JCDR/2015/12921.6023

Akob, M. (2016). Influence workload, work ethic and job satisfaction toward teacher's performance (Study of Islamic-based school in Makasar- Indonesia). Advanced Research Journal of Management and Business Studies, 5(7), 172-177.

Ali, N. H. M., Hassan, S. A., Jailani, O., Zaremohzzabieh, Z., \& Lee, Z. J. (2020). The impact of supervisory styles on satisfaction of undergraduate counselling interns in Malaysia. Asian Journal of University Education, 16(3), 138-147. https://doi.org/10.24191/ajue.v16i3.11079 
Alrawahi, S., Sellgren, S. F., Altouby, S., Alwahaibi, N., \& Brommels, M. (2020). The application of Herzberg's two-factor theory of motivation to job satisfaction in clinical laboratories in Omani hospitals. Heliyon, 6(9), 1-9. https://doi.org/10.1016/j.heliyon.2020.e04829

Al-Sada, M., Al-Esmael, B., \& Faisal, M. N. (2017). Influence of organizational culture and leadership style on employee satisfaction, commitment and motivation in the educational sector in Qatar. EuroMed Journal of Business, 12(2), 163-188. https://doi.org/10.1108/EMJB-02-2016-0003

Amin, S., Arshad, R., \& Ghani, R. A. (2017). Spousal support and subjective career success: The role of work-family balance and career commitment as mediator. Jurnal Pengurusan (UKM Journal of Management), 50, 133-142. https:// doi.oeg/10.17576/ pengurusan-2017-50-12

Ather, S. M., \& Nimlathasan, B. (2006). Association between quality of work life (QWL) and job satisfaction (JS): A study of academic professionals of private universities in Bangladesh. The Chittagong University Journal of Business Administration, 21, 923.

https://www.researchgate.net/publication/205019610_Quality_of_Work_life_ QoWL_and_Job_Satisfaction_JS_A_Study_of_Academic_Professionals_of_Privat e_Universities_in_Bangladesh

Berberoglu, A. (2018). Impact of organizational climate on organizational commitment and perceived organizational performance: Empirical evidence from public hospitals. BMC Health Services Research, 18(1), 399. https://doi.org/10.1186/s12913-018-3149-z

Bibi, P., Ahmad, A., \& Majid, A. H. A. (2018). The impact of training and development and supervisor support on employees retention in academic institutions: The moderating role of work environment. Gadjah Mada International Journal of Business, 20(1), 113-131. https://doi.org/10.22146/gamaijb.24020

Blau, G. J. (1985). The measurement and prediction of career commitment. Journal of Occupational Psychology, 58(4), 277-288. https://doi.org/10.1111/j.20448325.1985.tb00201.x

Caldana, A. C. F., Eustachio, J. H. P. P., Sampaio, B. L., Gianotto, M. L., Talarico, A. C., \& da Silva Batalhão, A. C. (2021). A hybrid approach to sustainable development competencies: The role of formal, informal and non-formal learning experiences. International Journal of Sustainability in Higher Education (ahead of print), 1-24. https://doi.org/10.1108/ijshe-10-2020-0420

Cerci, P. A., \& Dumludag, D. (2019). Life satisfaction and job satisfaction among university faculty: The impact of working conditions, academic performance and relative income. Social Indicators Research, 144(2), 785-806. https://doi.org/10.1007/s11205-018-02059-8

Choi, H., \& Chiu, W. (2017). Influence of the perceived organizational support, job satisfaction, and career commitment on football referees' turnover intention. Journal of Physical Education and Sport, 17, 955-959. https://doi.org/10.7752/jpes.2017.s3146

Chong, Y., \& Thi, L.-S. (2020). University freshman mentoring effectiveness and scale enhancement. Asian Journal of University Education, 16(4), 181-189. https://doi.org/10.24191/ajue.v16i4.11950

Clarke, M. (2015). Creating a supportive working environment in European higher education [technical report]. Education International Research Institute.

de Lourdes Machado-Taylor, M., Meira Soares, V., Brites, R., Brites Ferreira, J., Farhangmehr, M., Gouveia, O. M. R., \& Peterson, M. (2016). Academic job satisfaction and motivation: Findings from a nationwide study in Portuguese 
higher education. Studies in Higher Education, 41(3), 541-559. https://doi.org/10.1080/03075079.2014.942265

De Sousa Sabbagha, M., Ledimo, O., \& Martins, N. (2018). Predicting staff retention from employee motivation and job satisfaction. Journal of Psychology in Africa, 28(2), 136-140.

https://doi.org/10.1080/14330237.2018.1454578

Dorenkamp, I., \& Ruhle, S. (2019). Work-life conflict, professional commitment, and job satisfaction among academics. The Journal of Higher Education, 90(1), 56-84. https://doi.org/10.1080/00221546.2018.1484644

Duffy, R. D., England, J. W., Douglass, R. P., Autin, K. L., \& Allan, B. A. (2017). Perceiving a calling and well-being: Motivation and access to opportunity as moderators. Journal of Vocational Behavior, 98, 127-137. https://doi.org/10.1016/j.jvb.2016.11.003

Eisenberger, R., Huntington, R., Hutchison, S., \& Sowa, D. (1986). Perceived organizational support. Journal of Applied Psychology, 71(3), 500-507. https://doi.org/10.1037/0021-9010.71.3.500

Escardíbul, J.-O., \& Afcha, S. (2017). Determinants of the job satisfaction of PhD holders: An analysis by gender, employment sector, and type of satisfaction in Spain. Higher Education, 74(5), 855-875. https://doi.org/10.1007/s10734-016-0081-1

Franke, G., \& Sarstedt, M. (2019). Heuristics versus statistics in discriminant validity testing: A comparison of four procedures. Internet Research, 29(3), 430-447. https:// doi.org/10.1108/IntR-12-2017-0515

Gendron, T., Welleford, E. A., Pelco, L., \& Myers, B. J. (2016). Who is likely to commit to a career with older adults? Gerontology \& Geriatrics Education, 37(2), 208-228. https://doi.org/10.1080/02701960.2014.954042

Hair, J. F., Sarstedt, M., \& Ringle, C. M. (2019). Rethinking some of the rethinking of partial least squares. European Journal of Marketing, 53(4), 566-584. https:// doi.org/10.1108/EJM-10-2018-0665

Hair Jr, J. F., Howard, M. C., \& Nitzl, C. (2020). Assessing measurement model quality in PLS-SEM using confirmatory composite analysis. Journal of Business Research, 109, 101-110. https:// doi.org/10.1016/j.jbusres.2019.11.069

Hair Jr, J. F., Sarstedt, M., Hopkins, L., \& Kuppelwieser, V. G. (2014). Partial least squares structural equation modeling (PLS-SEM): An emerging tool in business research. European Business Review, 26(2), 106-121. https://doi.org/10.1108/EBR-10-20130128

Halder, N. (2018). Investing in human capital: Exploring causes, consequences and solutions to nurses' dissatisfaction. Journal of Research in Nursing, 23(8), 659-675. https://doi.org/10.1177/1744987118807251

Hall, D. T., Yip, J., \& Doiron, K. (2018). Protean careers at work: Self-direction and values orientation in psychological success. Annual Review of Organizational Psychology and Organizational Behavior, 5, 129-156. https://doi.org/10.1146/annurevorgpsych-032117-104631

Hee, O. C., Ong, S. H., Ping, L. L., Kowang, T. O., \& Fei, G. C. (2019). Factors influencing job satisfaction in the higher learning institutions in Malaysia. International Journal of Academic Research in Business and Social Sciences, 9(2), 10-20. https://doi.org/10.6007/IJARBSS/v9-i2/5510

Henseler, J., Hubona, G., \& Ray, P. A. (2016). Using PLS path modeling in new technology research: Updated guidelines. Industrial Management \& Data Systems, 116(1), 2-20. https://doi.org/10.1108/IMDS-09-2015-0382 
Henseler, J., Ringle, C. M., \& Sarstedt, M. (2015). A new criterion for assessing discriminant validity in variance-based structural equation modeling. Journal of the Academy of Marketing Science, 43(1), 115-135. https://doi.org/10.1007/s11747-014-0403-8

Herzberg, F.I., Mausner, B., \& Snyderman, B. (1959). The motivation to work (2nd ed.). John Wiley.

Herzberg, F. I. (1966). Work and the Nature of Man. Wold.

Houston, D., Meyer, L. H., \& Paewai, S. (2006). Academic staff workloads and job satisfaction: Expectations and values in academe. Journal of Higher Education Policy and Management, 28(1), 17-30. https://doi.org/10.1080/13600800500283734

Hsiao, J.-M., \& Lin, D.-S. (2018). The impacts of working conditions and employee competences of fresh graduates on job expertise, salary and job satisfaction. Journal of Reviews on Global Economics, 7, 246-259. https://ideas.repec.org/a/lif/jrgelg/v7y2018p246-259.html

Imondi, P. J. N. (2011). The influence of workload on performance of teachers in public primary schools in Kombewa Division, Kisumu West District, Kenya (Master's dissertation). University of Nairobi.

Indarti, S., Fernandes, A. A. R., \& Hakim, W. (2017). The effect of OCB in relationship between personality, organizational commitment and job satisfaction on performance. Journal of Management Development, 36(10), 1283-1293. https://doi.org/10.1108/JMD-11-2016-0250

Inegbedion, H., Inegbedion, E., Peter, A., \& Harry, L. (2020). Perception of workload balance and employee job satisfaction in work organisations. Heliyon, 6(1), 1-9. https://doi.org/10.1016/j.heliyon.2020.e03160

Janib, J., Rasdi, R. M., Omar, Z., Alias, S. N., Zaremohzzabieh, Z., \& Ahrari, S. (2021). The relationship between workload and performance of research university academics in Malaysia: The mediating effects of career commitment and job satisfaction. Asian Journal of University Education, 17(2), 85-99. https://doi.org/10.24191/ajue.v17i2.13394

Kenny, J. (2018). Re-empowering academics in a corporate culture: An exploration of workload and performativity in a university. Higher Education, 75(2), 365-380. https:// doi.org/10.1007/s10734-017-0143-z

Kim, S. J., Song, M., Hwang, E., Roh, T., \& Song, J. H. (2020). The mediating effect of individual regulatory focus in the relationship between career commitment and job satisfaction. European Journal of Training and Development, 45(2/3), 166-180. https://doi.org/10.1108/EJTD-02-2020-0030

Laihonen, H., \& Mäntylä, S. (2017). Principles of performance dialogue in public administration. International Journal of Public Sector Management, 30(5), 414-428. https:// doi.org/10.1108/IJPSM-09-2016-0149

Liu, H.-L., \& Lo, V. (2018). An integrated model of workload, autonomy, burnout, job satisfaction, and turnover intention among Taiwanese reporters. Asian Journal of Communication, 28(2), 153-169. https://doi.org/10.1080/01292986.2017.1382544

Liu, J., Yu, W., Ding, T., Li, M., \& Zhang, L. (2019). Cross-sectional survey on job satisfaction and its associated factors among doctors in tertiary public hospitals in Shanghai, China. BMJ Open, 9(3), 1-10. http://dx.doi.org/10.1136/bmjopen2018-023823

Marsaditha, P. H. (2017). The influence of work load, job satisfaction, and working environment towards woman work life balance (Case study in Pt Hasta Ayu Nusantara Jakarta) (PhD thesis). President University, West Java, Indonesia. 
Mudrak, J., Zabrodska, K., Kveton, P., Jelinek, M., Blatny, M., Solcova, I., \& Machovcova, K. (2018). Occupational well-being among university faculty: A job demandsresources model. Research in Higher Education, 59(3), 325-348. https://doi.org/10.1007/s11162-017-9467-x

Naseer, S., Raja, U., Syed, F., \& Bouckenooghe, D. (2018). Combined effects of workplace bullying and perceived organizational support on employee behaviors: Does resource availability help? Anxiety, Stress, \& Coping, 31(6), 654-668. https://doi.org/10.1080/10615806.2018.1521516

Newman, A., Nielsen, I., Smyth, R., Hirst, G., \& Kennedy, S. (2018). The effects of diversity climate on the work attitudes of refugee employees: The mediating role of psychological capital and moderating role of ethnic identity. Journal of Vocational Behavior, 105, 147-158. https://doi.org/10.1016/j.jvb.2017.09.005

Osifila, G. I., \& Aladetan, T. A. (2020). Workload and lecturers' job satisfaction in Adekunle Ajasin University, Akungba-Akoko, Ondo State, Nigeria. Journal of Education and Learning (EduLearn), 14(3), 416-423. https://eric.ed.gov/?id=EJ1266299

Prieto, I. M., \& Pérez-Santana, M. P. (2014). Managing innovative work behavior: The role of human resource practices. Personnel Review, 43(2), 184-208. https://doi.org/10.1108/PR-11-2012-0199

Purba, S. D. (2017). Career management dan subjective career success: Dapatkah meningkatkan kepuasan kerja wanita karir? [Career management and subjective career success: Can women's job satisfaction improve their career?]. MIX: Jurnal Ilmiah Manajemen, 7(1), 113-131.

Ringle, C. M., Sarstedt, M., Mitchell, R., \& Gudergan, S. P. (2020). Partial least squares structural equation modeling in HRM research. The International Journal of Human Resource Management, 31(12), 1617-1643. https:// doi.org/10.1080/09585192.2017.1416655

Sabagh, Z., Hall, N. C., \& Saroyan, A. (2018). Antecedents, correlates and consequences of faculty burnout. Educational Research, 60(2), 131-156. https://doi.org/10.1080/00131881.2018.1461573

Singh, J. K., \& Jain, M. (2013). A study of employees' job satisfaction and its impact on their performance. Journal of Indian Research, 1(4), 105-111.

Song, S. L., Barker, K., \& Kerbyson, D. (2013). Unified performance and power modeling of scientific workloads. Proceedings of the 1st International Workshop on Energy Efficient Supercomputing, 4, 1-8. https:// doi.org/10.1145/2536430.2536435

Suifan, T. S., Abdallah, A. B., \& Al Janini, M. (2018). The impact of transformational leadership on employees' creativity: The mediating role of perceived organizational support. Management Research Review, 41(1), 113-132. https://doi.org/10.1108/MRR-02-2017-0032

Tight, M. (2010). Are academic workloads increasing? The post-war survey evidence in the UK. Higher Education Quarterly, 64(2), 200-215. https://doi.org/10.1111/j.1468-2273.2009.00433.x

Toropova, A., Myrberg, E., \& Johansson, S. (2021). Teacher job satisfaction: The importance of school working conditions and teacher characteristics. Educational Review, 73(1), 71-97. https://doi.org/10.1080/00131911.2019.1705247

Wolf, P., Harboe, J., Sudbrack Rothbarth, C., Gaudenz, U., Arsan, L., Obrist, C., \& Van Leeuwen, M. (2021). Non-governmental organisations and universities as transition intermediaries in sustainability transformations building on grassroots initiatives. Creativity and Innovation Management, 30(3), 596-618. https://doi.org/10.1111/caim.12425

Xie, B., Zhou, W., Huang, J. L., \& Xia, M. (2017). Using goal facilitation theory to explain the relationships between calling and organization-directed citizenship behavior 
and job satisfaction. Journal of Vocational Behavior, 100, 78-87. https://doi.org/10.1016/j.jvb.2017.03.001

Zhang, J., Wu, Q., Miao, D., Yan, X., \& Peng, J. (2014). The impact of core self-evaluations on job satisfaction: The mediator role of career commitment. Social Indicators Research, 116(3), 809-822. https://doi.org/10.1007/s11205-0130328-5 